\title{
Stormwater Ponds in the
} Southeastern U.S. Coastal Plain: Hydrogeology, Contaminant Fate, and the Need for a Social-Ecological Framework

\author{
Barbara Beckingham*, Timothy Callahan and Vijay Vulava \\ Department of Geology and Environmental Geosciences, College of Charleston, Charleston, SC, United States
}

\section{OPEN ACCESS}

Edited by:

Hallie Eakin,

Arizona State University, United States

Reviewed by:

Brandon Kyle Winfrey,

Monash University, Australia

Isaac Dennis Amoah,

Durban University of Technology,

South Africa

*Correspondence:

Barbara Beckingham

beckinghamba@cofc.edu

Specialty section

This article was submitted to Water and Wastewater Management, a section of the journal

Frontiers in Environmental Science

Received: 30 April 2019

Accepted: 08 July 2019

Published: 24 July 2019

Citation:

Beckingham B, Callahan T and Vulava V (2019) Stormwater Ponds in the Southeastern U.S. Coastal Plain: Hydrogeology, Contaminant Fate, and

the Need for a Social-Ecological Framework. Front. Environ. Sci. 7:117.

doi: 10.3389/fenvs.2019.00117
In lowland coastal regions of the southeastern United States, stormwater ponds are being built as the "green infrastructure" best management practice of choice for addressing the hydrologic changes associated with rapid urban and suburban development. In addition to dampening storm flows, stormwater ponds may provide pollution control and other ecosystem services. However, ponds are not native to this landscape. This review summarizes what is known about the effectiveness of these engineered ponds, which take many shapes and forms, in the context of hydrology, contaminant fate, and management. Research needs are identified and include evaluating pond performance and redesign options more comprehensively and applying a social-ecological framework for the future of stormwater pond management.

Keywords: stormwater, pond, green infrastructure, urban development, coastal plain, best management practice

\section{INTRODUCTION}

The southeastern coastal plain areas of the United States, comprising North Carolina (NC), South Carolina (SC), Georgia (GA), and Florida (FL) (Figure 1), have experienced population growth in recent decades that exceeds the national average (Table 1). This growth is expected to continue, and within a coastal area that is already more densely populated than inland counties (NOAA, 2013). According to the National Oceanographic and Atmospheric Association (NOAA) Coastal Change Analysis Program, between 1996 and 2010 the Southeast had the fastest rate of change in developed land of any coastal region in the country, and experienced development at a pace of 1 football field ( $~ 5,350 \mathrm{~m}^{2}$, or $3 / 4$ of a standard soccer field) every $13 \mathrm{~min}$ (https://coast.noaa.gov/digitalcoast/ training/regional-land-cover-change.html). This region also supports many industries, including recreation, tourism, and fisheries, which are closely linked to numerous ecosystem services and depend on well-managed water resources. In 2015, each state in the region attributed 9.5-14.5\% of total jobs on average in coastal counties to "ocean jobs," primarily tourism and recreation, but also including shipping activities and living resources (although not counting self-employment) (https://coast.noaa.gov/snapshots/). Altogether, coastal counties contributed 25\% of the 2014 total gross domestic product of the states in the Southeast region (NOEP, 2016).

Impacts of increasing population, economy, and the resultant land cover and land use change expected for this region into the future (Terando et al., 2014) include changes to the social and political fabrics of the region as well as alteration in coastal geomorphology, increased pollution and eutrophication, and biodiversity loss (National Research Council (NRC), 2008). Stormwater runoff 


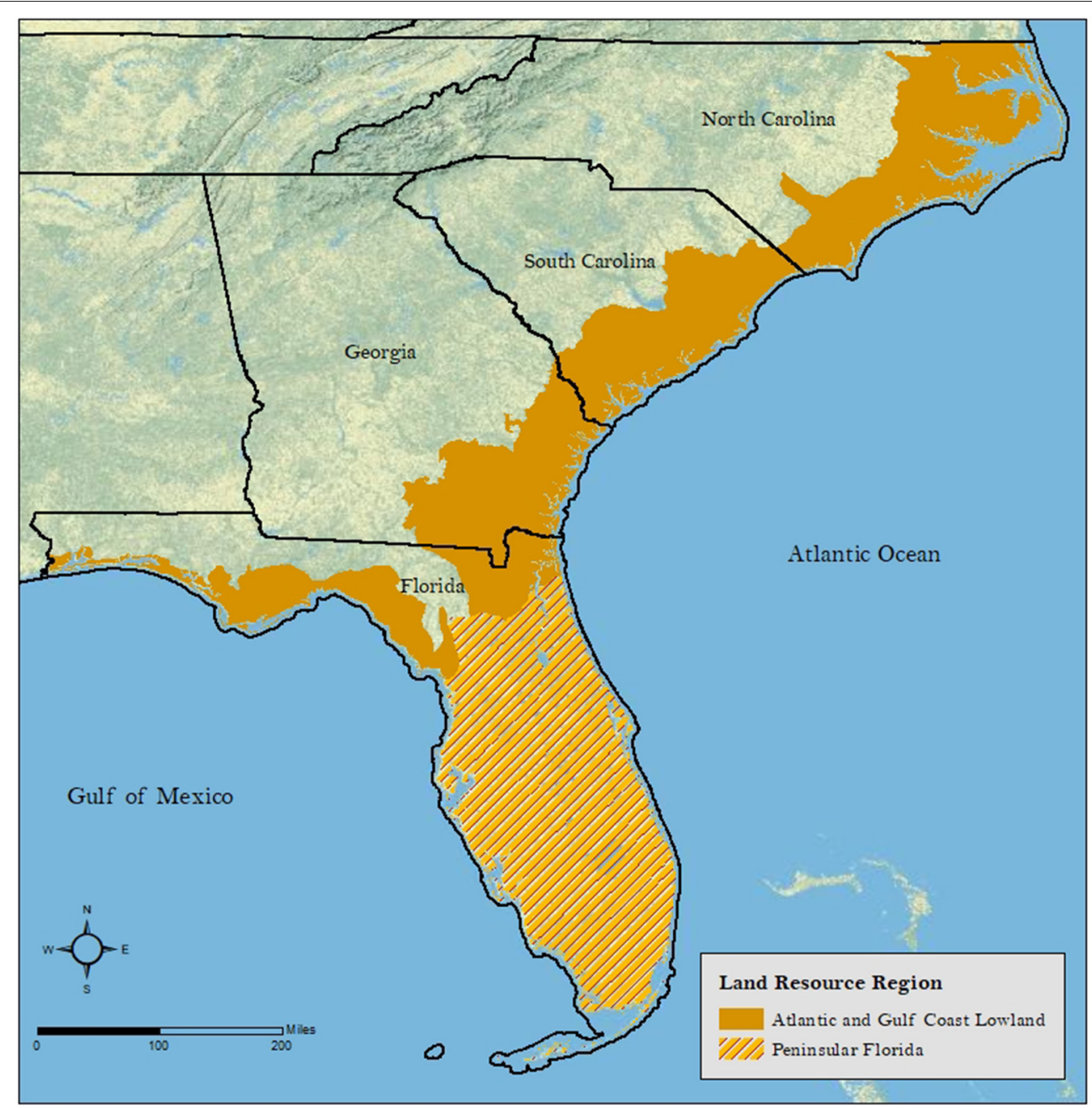

FIGURE 1 | Coastal regions of the Southeastern United States defined using the U.S. Department of Agriculture-classified Land Resource Regions of the outer coastal plain (Atlantic and Gulf Coast Lowland) and peninsular Florida (Map data source: https://www.nrcs.usda.gov/wps/portal/nrcs/detail/national/technical/nra/ nri/?cid=nrcs143_013721).

from impervious surfaces, specifically in urban and urbanizing land uses, is widely considered the primary stressor to aquatic ecosystems around the world and there is, therefore, a need to mitigate these impacts using stormwater control measures (National Research Council (NRC), 2008). Urban development along coastlines worldwide is leading to increased reliance on various types of best management practices (BMPs) to mitigate water flow and water quality concerns, and guidance is increasingly available to planners and builders (e.g., Ellis et al., 2014; Chang et al., 2018).

Over the same period from 1970 to today when U.S. coastal populations have risen dramatically, there have been shifts in structural controls used for stormwater management reflecting various regulatory, technological, and economic drivers (Anderson et al., 2002; National Research Council (NRC), 2008; McPhillips and Matsler, 2018). In many cases, conventional stormwater pipes and conveyances discharging directly to receiving water bodies, often termed "gray" stormwater infrastructure, have fallen out of favor due to unintended consequences associated with the drastic alteration of streamflows and water quality (e.g., Walsh et al., 2005). Where space was available, and where encouraged by stormwater control regulations passed primarily since the 1980s, preference shifted to softer engineering controls, or "green" infrastructure that aims to alleviate changes in water flows and quality post-development, while simultaneously providing other potential societal benefits. While there are a number of emerging green structural stormwater BMPs, such as constructed wetlands, bioswales, and infiltration basins, stormwater ponds are currently the most widely used for peak flow reduction and runoff treatment (National Research Council (NRC), 2008).

In the coastal plain regions, which are characterized by relatively shallow water tables and low hydraulic gradients, stormwater ponds with a permanent pool, typically referred to as wet detention ponds, dominate and are widely visible landscape features. For example, demonstrating the proliferation 
TABLE 1 | Population change in the southeastern U.S. coastal plain states.

\begin{tabular}{|c|c|c|c|c|c|}
\hline \multirow[t]{2}{*}{ State } & \multicolumn{2}{|c|}{ Coastal plain (Figure 1)* } & \multicolumn{3}{|c|}{ Coastal counties (NOAA, 2013) } \\
\hline & 2010 population & 1990-2010 historical change (\%) & 2010 population & 1970-2010 historical change (\%) & 2010-2020 projected change (\%) \\
\hline NC & $1,406,816$ & 46 & 999,064 & 92 & 10 \\
\hline SC & $1,507,518$ & 40 & $1,241,048$ & 127 & 23 \\
\hline GA & 948,607 & 44 & 563,967 & 82 & 19 \\
\hline $\mathrm{FL}$ & $18,214,732$ & 42 & $14,468,197$ & 165 & 16 \\
\hline U.S. & - & 24 & - & $52 \wedge$ & - \\
\hline
\end{tabular}

${ }^{\star}$ Census data obtained from U.S. Census Bureau (2011) and Manson et al. (2018). ^Average population change of all U.S. counties.

of stormwater ponds during development, an estimated 10,000 wet detention ponds have been surveyed in urban areas in southwest Florida, most being constructed since 1980 (Thomas and Lucius, 2016). In the 20 coastal counties of North Carolina, stormwater ponds are the most commonly selected stormwater control measure on post-construction stormwater permits, although the number of ponds is yet unknown (Gona, 2016; NC DEQ personal communication, 2021). In a study of 511 ponds in SC, wet detention was the most frequently used type (Drescher et al., 2007). Further, analysis of aerial imagery-based inventories of wet detention ponds has found about 100 ponds were created per year on average in both the Myrtle Beach and Charleston metropolitan areas of SC between 1994 and 2013, with annual rates of change in pond area roughly tracking the rate of change of total developed land area (Smith et al., 2018). Ponds are often a highlighted feature of residential developments that have been designed over the past few decades (Figure 2).

Green stormwater infrastructure provides a host of potential ecosystem services, although these have been mostly unquantified (Prudencio and Null, 2018). Traditionally engineered with the objective to control flooding, stormwater ponds act as reservoirs to collect water and soil erosion from the surrounding landscape and to dampen the storm pulse to receiving water bodies. This function is important for integrity of downstream structures, and ecosystems therein (Persson and Wittgren, 2003). Over time, it has been shown that ponds can serve many functions; they provide ecological habitat for birds and aquatic life (Hassall and Anderson, 2015; Greenfield et al., 2018), either trap or act as a gateway for the transport of various environmental pollutants to receiving bodies (Van Metre et al., 2000; Hathaway et al., 2009; Thapalia et al., 2010; Koch et al., 2014; Gold et al., 2017b; McCabe et al., 2021), sequester carbon (Schroer et al., 2018), provide cultural and ecosystem services (Moore and Hunt, 2012), and can serve as a valued, aesthetic feature of a community (Ghermandi and Fichtman, 2015). By averting and storing runoff on-site, ponds open up the possibility for rainwater use, such as for landscape irrigation, saltwater intrusion barriers, drinking water aquifer recharge, augmentation of potable water reservoirs, non-potable water use in buildings, and baseflow augmentation to improve freshwater habitat and recreational use depending on water quality and need (Grebel et al., 2013). Stormwater ponds therefore serve as a public good, although they are often privately owned and managed. How ponds perform hydrologically and biogeochemically influence how they are viewed as either environmental assets or liabilities.
In this review, we aim to illustrate that the water quality and quantity functions of stormwater ponds, as an environmental engineered landscape feature, have important implications for the social and ecological systems of the southeastern United States, and vice-versa, that require further multidisciplinary study. The case for recognizing stormwater infrastructure as a social-ecological system has been made recently (e.g., Flynn and Davidson, 2016), and the southeastern U.S. coastal plain region offers a unique hydrogeologic, ecologic, and socio-political setting to study the functioning of stormwater ponds and their impact on coastal ecosystem services. Here, discussion of "stormwater ponds" is in specific reference to "wet detention basins." We recognize that other designs such as dry detention basins also provide similar services, but dry basins are ephemeral in their water-holding characteristics, usually due to higher soil permeability and/or deeper water table conditions. Thus, dry basins operate differently to affect the routing of stormwater and fate of contaminants in the landscape (Ellis et al., 2014). We focus on the southeastern Atlantic coastal plain within NC, SC, GA, and FL, as well as the FL peninsula because of cohesiveness in landscape topography, ecology and land management (Figure 1). Namely, the region spans the U.S. Environmental Protection Agency Level III Ecoregions of the Middle Atlantic Coastal Plain (NC, SC), Southern Coastal Plain (GA, FL), and Southern FL Coastal Plain. The region is also identified as the Southeast region for the U.S. EPA/NOAA Coastal Change Analysis Program and comprises the Outer Coastal Plain and Florida Peninsula Land Resource Areas defined by the U.S. Department of Agriculture Natural Resources Conservation Service.

\section{DISCUSSION}

\section{Geologic and Hydrologic Context}

There are generally few natural lakes and ponds in the southeastern coastal plain. Water resources in this region include large reservoirs on dammed rivers as well as deep, confined aquifers in carbonate formations of Eocene Epoch (34 million years) or older age. This region is characterized by a generally flat topography, with beach ridges or terraces (modern and ancient, dating back to past high stands of sea level through the Cenozoic Era) separated by lagoonal back-barrier areas between the terraces. One example of natural "ponds" includes Carolina Bay wetlands (Pyzoha et al., 2008); however, these coastal plain features are uncommon because of well-drained soils in the former beach ridge systems and the tendency 

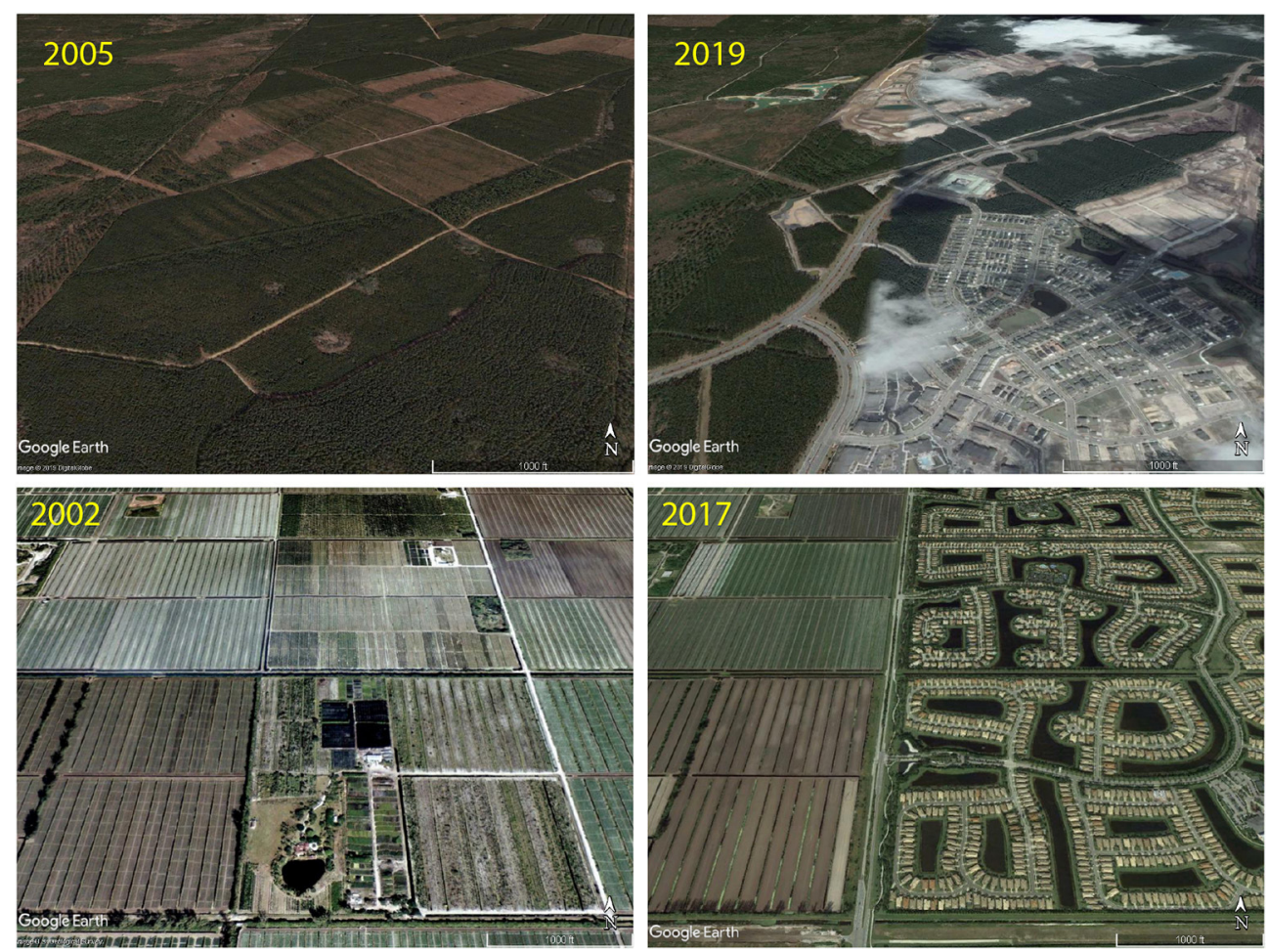

FIGURE 2 | Land use transitions to residential development highlight the use of wet detention ponds for stormwater management in the coastal zone. Upper panel: outside Charleston, South Carolina, 33॰3'33.01 “N, 808'48.85”W in the Sawmill Branch Creek watershed (HUC12: 030502010601); lower panel: outside Boca Raton, FL, 26 30'35.22“N, 80'11'29.72”W, in the Hillsborough Canal watershed (HUC12: 030902061101). Stormwater ponds in the two developed panels to the right side are visible in the form of dark areas surrounded by homes/buildings. In the upper-right panel, two large ponds are visible near the center, while many ponds (round or elongated) are visible in the lower-right panel. Upper-right panel, through partial cloud cover, also shows expansion of new developments with clear cutting and re-grading of the pre-existing managed-forested landscapes, and a borrow pit is found in the top-left corner. The lower-left panel also shows (at bottom-center) prior agricultural use of ponds.

for concentrated flow on poorly-drained clay-sized sediments to form streams. Another example are karstic depressions in peninsular Florida (Galloway et al., 1999), which are more common, as are coastal lagoons (Lapointe et al., 2015; Barile, 2018), and both are important water resources in a region of nearsurface carbonate lithology. The better connections of surface water and groundwater in peninsular FL result in important differences of water resources, both natural and engineered, compared to that of the rest of the southeastern coastal plain.

Another factor for sparse natural littoral surface water systems in the region is the relatively balanced water budget. Average annual rainfall in the southeastern U.S. is about $110 \mathrm{~cm}$ in the upper (inner) coastal plain to about $130 \mathrm{~cm}$ in the lower coastal plain of South Carolina (Amatya et al., 2018) to $150 \mathrm{~cm}$ in northern Florida (NOAA, 2019). This water input has been, on average, approximately balanced by evapotranspiration (ET) of coastal plain forests (Harder et al., 2007; Callahan et al., 2017; Amatya et al., 2018). Freshwater runoff from any undeveloped uplands of the coastal plain is relatively small in volume because of the relative ease of water infiltration into the sandy upland soils, however, with land development in and around metropolitan areas, increased impervious surface coverage has led to larger volumes of stormwater runoff to receiving water bodies, including streams and rivers, tidal creeks and marshes, and the coastal ocean (Sanger et al., 2015).

To handle the increase in stormwater flow, stormwater wet detention ponds have been built across the southeastern U.S. coastal plain, as described above. Stormwater ponds of varying size now exist across the region where previously only a small collective area of impounded streams and creeks existed, which was typically for the purpose of freshwater resources for rural needs (livestock, waterfowl, irrigation and recreation purposes; see for example Figure 2). Stormwater ponds are classified generally according to the way they store and route runoff. In the broadest terms, ponds are either wet or dry-having a permanent pool of water or not. Whether a pool is permanently wet or dries up between rain events is a function of connectivity with surface and ground waters, soil properties, and design of outlet structures. For instance, under similar geologic settings a permanent pool of water can be retained by setting outlet structures at higher elevations than for a dry detention basin and/or by lining the bottom of ponds with a low-permeability material (Persson and Wittgren, 2003; Weiss et al., 2007).

Stormwater routing patterns have received some study in the lower coastal plain of South Carolina (Harder et al., 2007; Epps et al., 2012), with some attention placed on calibrating 
runoff models like TR-55 or Curve Number Approach to the low-gradient topography (Blair et al., 2014a,b; Blair and Sanger, 2016). The variable soil drainage characteristics of this region may explain the wide range of runoff fraction of precipitation for individual storm events. For example, Epps et al. (2012) found for a natural forested watershed with sandy soils and shallow water table condition, total storm runoff was as little as $0 \%$, and up to $93 \%$ of precipitation for different storm events, with a median value of 18\% (see Table 3 in Epps et al., 2012). Such variability in this area with little disturbance of forest systems (albeit with past drainage structures such as ditches, constructed decades ago) leads to uncertainty in the stormwater dynamics of developed lands and the engineering of stormwater retention structures. Site details such as topography, development soil fill material, ditching, and pond design details, together with runoff predictive models that include soil data (e.g., Fennessey et al., 2001), should inform stormwater managers to plan for and mitigate stormwater inputs.

Nuisance flooding (Fennessey et al., 2001; Underwood, 2018) and major storm event flooding are hazards to property near ponds that may be exacerbated by a lack of understanding of the hydrology of ponds in the coastal zone. Property can experience nuisance flooding following the construction of large adjacent impervious areas when a pond is constructed directly upslope, as is done for in-fill residential or commercial development. This may instigate a local increase in the water table if the pond is not lined with low permeability clay or geotextile to minimize groundwater seepage, or if an extreme event causes pond overflow or bank failure. These hazards can occur when the site plan mispredicts the predevelopment runoff of a watershed and/or uses property boundaries to define the catchment area for the ponds, as is commonly done (Fennessey et al., 2001). This can additionally impair a pond's ability to operate to design standards. This region is also uniquely prone to hurricanes/tropical storm precipitation events and bears the most risk from hurricanes compared to other coastal U.S. populations (Wilson and Fischetti, 2010). The hydrologic cycle is expected to intensify under scenarios of future climate change. Changing patterns of precipitation in the Southeast U.S. includes an expected increase in heavy downpours (Carter et al., 2018). Although stormwater ponds are not designed to alleviate flooding from major storm events, one can conclude from this that climate non-stationarity may ultimately affect the size of a "design storm": the event return period and amount of rainfall that policy dictates ponds should be able to hold and slowly release. The ultimate result of improperly located or sized stormwater basins may be additional financial burden on community residents impacted by flooding or increased maintenance, as well as broader watershed-scale impacts.

Many stormwater ponds could be conceptualized as engineered "headwaters" connecting landscapes and larger water bodies- and in the coastal zone, these water bodies can be tidally influenced. For instance, 57\% of the development-related ponds surveyed in coastal SC are found within $3 \mathrm{~km}$ of a significant receiving water body (i.e., "river, tidal creek, or other coastal water body $>66$ feet in width, as defined by the National Wetland Inventory") (Smith et al., 2018). The water budget of ponds in proximity to tidal creeks will dictate whether or not pond salinity may be brackish, which may be the case if there is significant surface water exchange (via "outlet" structures) or groundwater connectivity, or especially during drier seasons coinciding with periods of higher evapotranspiration. Ponds in coastal SC that are tidally influenced, especially with direct surface water connections, have been observed to range from low brackish to marine salinities (DeLorenzo and Fulton, 2009). Salinity dynamics in freshwater ponds in proximity to tidal bodies have also been observed due to groundwater connections (Wisniewski, 2014). The incidence of high tide flooding is increasing in the southeastern Atlantic coast region (Carter et al., 2018; NOAA, 2018), which has implications for stormwater management. For three coastal counties in SC where location of stormwater ponds was mapped, it was estimated that up to $20 \%$ of ponds were at or below the elevation of mean higher high water, indicating likelihood of tidal groundwater exchange (Smith et al., 2018). Contributing to complicated dynamics of storm water flows, the southeastern U.S. coastline has a geographically variable tidal range, with two high tides and two low tides occurring over a 25 -h cycle. The tidal amplitude ranges from about $1.2 \mathrm{~m}$ in both the northern coast of SC and along the Atlantic coast of Florida, $2 \mathrm{~m}$ in the central coast of SC, and $2.8 \mathrm{~m}$ in the southern coast of SC. While not conducting a complete water budget, Thomas and Lucius (2016) estimated a significant groundwater contribution (up to $\sim 15 \%$ ) to a stormwater pond in southwest Florida. Pond construction details (depth and whether the pond bottom is lined or unlined) will control this subsurface flux.

\section{Stormwater Flow and Pollution Control}

Wet detention ponds hold a permanent pool of water, have additional capacity to temporarily store water above the permanent pool to a design depth during storm events, and trap contaminants predominately through settling and biogeochemical transformation within the water column and sediment bed (see conceptual diagram, Figure 3). Hydrological, physical, and biogeochemical processes operate in concert to drive the function of stormwater pond systems. Stormwater runoff and groundwater interflow entering ponds carries with it an array of contaminants of concern, including inorganic (e.g., nutrients and metals) and organic chemicals (e.g., pesticides, herbicides, flame retardants, phthalates), particulate matter (e.g., sediments, oxygen-consuming substances, and anthropogenic litter including microplastics), and pathogens (e.g., bacteria and viruses), all of which are removed with various efficiencies depending on pond- and contaminant-specific attributes (Vulava et al., 2018). For example, concentrations of pesticides in stormwater ponds in coastal South Carolina have been correlated with temperature and rainfall, and to concentrations in adjacent tidal creeks (e.g., pyrethroids and imidacloprid), which demonstrates connections between runoff, stormwater ponds, and receiving waters (DeLorenzo et al., 2012). Significant groundwater fluxes of nutrients (ammonium and nitrate) to and from stormwater ponds have also been observed (Bunker, 2004).

Broad ranges in pollutant removal efficiencies from stormwater runoff by wet detention ponds are reported in published literature. Wet detention basin performance cited by BMP guidebooks for South Carolina and Florida, as examples, 

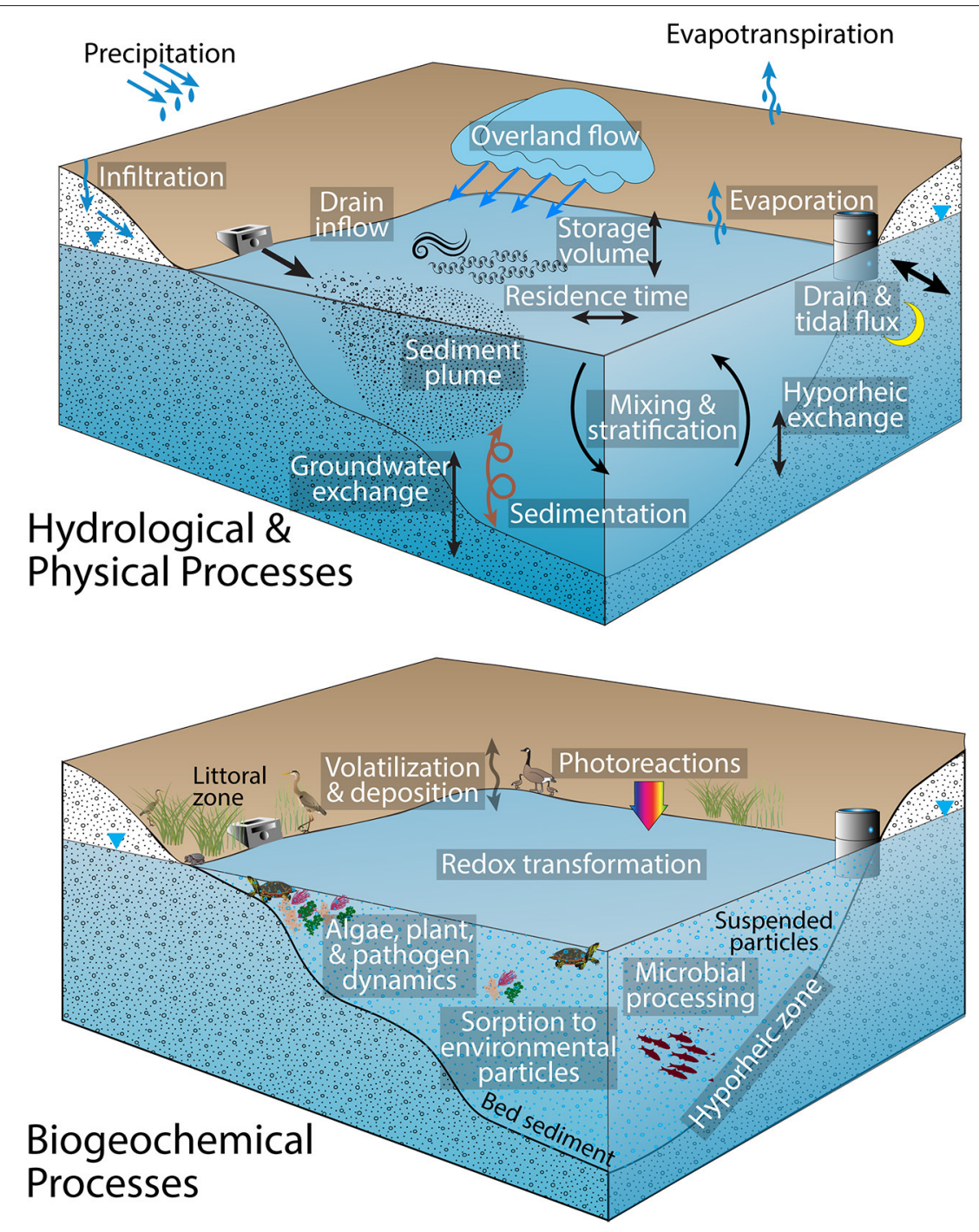

FIGURE 3 | Conceptual model outlines hydrological and physical (upper), and biogeochemical processes (lower) that occur in stormwater ponds. The hydrological and physical processes reflect a typical hydrologic cycle as well as stormwater runoff and associated sediment and contaminant transport. The biogeochemical processes reflect various consumption, sequestration, and transformation pathways of contaminants in stormwater ponds. (Acknowledgment: some elements of this conceptual model are courtesy of the Integration and Application Network, University of Maryland Center for Environmental Science, ian.umces.edu/symbols/).

are presented in Table 2. These ranges reflect "typical" behavior but may not capture the range of removal efficiencies across storm events of different magnitudes, and are not specifically taken from studies of wet ponds in the coastal plain. For example, negative removals indicating ponds as sources of pollutants to receiving water bodies are also reported in coastal case studies (e.g., Messersmith, 2007; Gold et al., 2017b). Also, the ranges in total nitrogen removal in Table 2 for SC and FL case studies agree with the average of $40 \pm 31 \%$ for wet ponds in a recent comprehensive data synthesis (Koch et al., 2014), but it's important to note that efficiency depends on nutrient form (e.g., nitrate or ammonium vs. organic-N) and this applies to other contaminants of concern as well (e.g., metals). It is also worth cautioning that comparing storm-by-storm pollutant removal efficiencies is complicated by variation in study design, data analysis and site hydrology, and it has been recommended that alternative measures for evaluating effectiveness, such as statistical comparisons of longer-term influent and effluent data and evaluation of effluent water quality, be more routinely applied (Strecker et al., 2001).

While serving to alleviate flooding and downstream water quality concerns when operating effectively, stormwater ponds may also present localized human and ecological health risks. Because ponds capture pollutants from stormwater runoff, removal and disposal of these sediments represents an opportunity to reduce contaminant loads to receiving water bodies; however, pond sediments may contain concentrations of trace metals or organic contaminants of concern above sediment quality guidelines (Weinstein et al., 2010; Baalousha et al., 2018). In addition to receiving pathogenic organisms in 
TABLE 2 | Average pollutant removal capabilities summarized in Best Management Practice manuals for wet detention ponds based on studies conducted in South Carolina and Florida.

\begin{tabular}{lcc}
\hline Pollutant & \multicolumn{2}{c}{ Average percent removal } \\
\cline { 2 - 3 } & $\begin{array}{l}\text { South Carolina (SC } \\
\text { DHEC, 2005) }\end{array}$ & $\begin{array}{l}\text { Florida (Harper and } \\
\text { Baker, 2007) }\end{array}$ \\
\hline Total suspended & $65-80 \%$ & $55-94 \%$ \\
solids & & $1-92 \%$ \\
Copper & $40-65 \%$ & $32-96 \%$ \\
Zinc & $50-75 \%$ & $40-96 \%$ \\
Lead & $60-85 \%$ & $4-63 \%$ \\
Total nitrogen & $35-45 \%$ & $39-93 \%$ \\
Total phosphorus & $50-70 \%$ & $50-90 \%$ \\
Biochemical & Not reported & \\
oxygen demand & & \\
\hline
\end{tabular}

non-point source runoff, stormwater ponds may also provide the ideal conditions for their proliferation or attract wildlife leading to in-pond sources (Hathaway et al., 2009; Greenfield et al., 2018). Emergence of harmful algal blooms in ponds can impact immediate or downstream human and ecological communities (Lewitus et al., 2003, 2008; Serrano and DeLorenzo, 2008; Greenfield et al., 2017). Developing a framework for human and ecological health risk assessment for engineered stormwater ponds is complicated by having to define endpoints of impairment and appropriate indicators (Tixier et al., 2011).

The factors that are critical to influencing pond function, specifically hydraulic detention and contaminant sequestration, are based on mechanistic and empirical knowledge from the fields of engineering and natural sciences (see for review, Blecken et al., 2017 and Vulava et al., 2018). Stormwater pond design and maintenance manuals outline and regulate critical features (such as dimension, slopes, hydraulic head, depths, pipe structures and ways to maintain them; e.g., U.S. EPA, 2009). Pollutant removal processes occur through a variety of mechanisms, including physical (e.g., sedimentation), chemical (e.g., sorption, photodegradation), and biological (e.g., uptake and transformation of nutrients, or particulate trapping by vegetation) (Figure 3).

Sedimentation in particular is an important process that protects downstream water quality, and is influenced by pond design (e.g., geometry, forebay or other installation), hydrology (e.g., retention time, potential for short-circuiting), the nature of suspended solids (e.g., allochthonous, autochthonous, and carbon or mineral composition), management activities that impact particle capture (e.g., vegetation planting/control or dredging maintenance), and even storm event-specific characteristics (e.g., hydrograph, wind speed and direction) (Greb and Bannerman, 1997; Anderson et al., 2002; Scholes et al., 2008; Vezzaro et al., 2011; Gold et al., 2017a; Moore et al., 2017). In a study of 14 stormwater wet detention ponds in coastal SC in residential urban and suburban communities, Schroer et al. (2018) measured sedimentation rates spanning $0.06-0.5 \mathrm{~cm}$ $\mathrm{y}^{-1}$ and detected sequestration of carbon and nitrogen through burial. However, in another case study in SC, Messersmith
(2007) observed a single stormwater pond lost 36\% volume and the last pond in a series of 5 linked ponds lost 15\% volume in 5-7 years post-construction. Sedimentation in stormwater ponds is beneficial for improving water quality in downstream receiving water bodies; however, over time the reduction in effective settling depth, water storage volume and residence time of stormwater in ponds can lead to ineffectiveness at removing pollutants or buffering storm pulses.

Residence time (RT) is a parameter that controls sedimentation and biogeochemical transformation and has been cited as the factor that is most limiting to water quality improvement in stormwater ponds (although other factors, such as light penetration, redox environment, and plants are notable for certain constituents) (Mallin et al., 2002; Weiss et al., 2007, 2008). Residence time is determined by pond volume and water discharge rates. Longer residence times over 7 days tend to result in more improved water quality through greater reduction in nutrients $(\mathrm{N}, \mathrm{P})$ and biochemical oxygen demand (Harper and Baker, 2007). However, residence time alone does not necessarily allow prediction of pollutant removal efficiencies (AMEC, 2012). Size, depth, and shape are important design criteria that have been observed to affect pollutant removal in stormwater ponds (e.g., Chiandet and Xenopoulos, 2016) and are a part of wet detention pond design criteria in states across the study region (SC DHEC, 2005; Harper and Baker, 2007; GA EPD, 2009; NC DEQ, 2017).

There are also seasonal variables that can affect wet detention pond performance. For instance, stratification or eutrophication are phenomenon that are often observed in stormwater ponds and lakes in the southeastern U.S., especially in summer, as affected by pond depth, nutrient loads and the sub-tropical climate at the coasts (Lewitus et al., 2003, 2008; Harper and Baker, 2007; DeLorenzo and Fulton, 2009; Gold et al., 2017a). These conditions can impact the availability of oxygen in pond sediment pore waters and subsequently the redox conditions, which control processing of nutrients, speciation of metals, and degradation of organic compounds, or may lead to proliferation of pathogenic microbes and harmful algae. Harmful algal blooms and low dissolved oxygen can result in fish kills in ponds (Kirkwood, 2009), and may augment occurrences of pathogenic Vibrio bacteria (Greenfield et al., 2017). The extent of tidal influence on ponds, which may vary seasonally, can also affect pond ecology and pollutant removal, such as by shifting bacterial assemblages responsible for nutrient transformation (Lewitus et al., 2008; DeLorenzo and Fulton, 2009).

As a wet detention pond (and infrastructure, generally) ages, continued performance is contingent upon maintenance and local stewardship. "Lifetime" represents the duration that the stormwater control structure demonstrates acceptable functionality, after which replacement or significant maintenance would be required. The lifetime of wet detention ponds may be most impacted by rates of sedimentation and infill by organic matter and debris (e.g., Anderson et al., 2002; Gold et al., 2017a; Thomas 2014). These rates are dependent upon many factors, and importantly in the Southeast U.S. could be controlled by relatively low landscape erosional potentials, relatively high year-round primary production (i.e., resulting 
in high levels of organic debris) and continuing development pressures. For instance, rapid urbanization or development "infill" occurring in the region, and the resulting increase in impervious cover within a stormwater pond watershed, can result in increased sedimentation in ponds (Schroer et al., 2018) that could produce accelerated maintenance demands. Maintenance to dredge accumulated sediment is recommended when the pond pool volume has been significantly diminished. For example, in South Carolina a loss of $25 \%$ of permanent pool volume is the benchmark recommended for dredging (SC DHEC, 2005). State of Florida requires that dredging be conducted when the specific "water quality volume" designed for sediment capture has been lost (FDOT, 2015). Decisions associated with maintenance activities, such as dredging, are generally borne by individuals, communities, or municipalities in accordance with responsibilities outlined by local systems of stormwater governance and are affected by the costs and perceived benefits of actions (Burnett and Mothorpe, 2018).

\section{Stormwater Pond Stewardship}

Environmental governance and stewardship are longstanding, constantly-evolving practices that tie policy with science through communication (Harrington and Hsu, 2018). Approaches are being developed by various "hard" and "soft" scientific communities for improving partnerships/cooperation/coordination among residents/private owners and state- and local-governments for stormwater pond stewardship, including understanding the costs and benefits of investment (Burnett and Mothorpe, 2018), as well as psychological preferences for how information is presented (Callahan et al., 2018), or who within a community is most receptive to messaging (Monaghan et al., 2016). Among insights gained, researchers have found that knowledge and valuation of stormwater pond function alone may not necessarily translate to acceptance of BMPs, especially if change is perceived as going against social norms (Monaghan et al., 2016). Further complicating sharing of knowledge about best practices across regions are barriers (actual or perceived) presented by political and institutional systems, such as governing patterns, legal codes, and funding mechanisms (Dolowitz, 2015).

There are various stakeholders that need to communicate with each other to exchange needs, desires and technical information, from individual homeowners, to homeowner associations, stormwater pond managers, scientists and engineers, and regulatory officials at multiple levels of governance. Multiple government agencies and non-profits may be involved with a municipality's stormwater management. Learning and exchange may stall when parties do not have a history of trust (Fennessey et al., 2001), are not open to fully discussing failures as openly as successes (Dolowitz, 2015), or when the political climate on an issue is contentious (Dow et al., 2013). There may be significant gaps in policy that affect the drive for evaluation, innovation, and transfer of best practices for stormwater pond management at the local level. Funding and staffing can also be an issue (Law et al., 2008). Stormwater professional organizations, watershed associations, and other organized meetings can help facilitate exchange. Web-based resources are also important; in a survey of Atlantic coastal plain communities, websites were identified as the preferred method for learning new information (Law et al., 2008). Interestingly, in a policy scan conducted of coastal South Carolina, information available pertaining to stormwater on county websites was variable, and 6 of 8 counties did not appear to have stormwater incorporated into their comprehensive plans or zoning (Dickes et al., 2016). Equivalent county-level policy scans in the rest of the southeastern coastal plain region do not appear to be available. Some communities, however, are incorporating stormwater into local watershed plans, such as Bluffton, SC, Valousa County, FL, Washington, NC, and Fort Steward, GA (Law et al., 2008). While, as stated by Drescher et al. (2011), "[i]n the past, stormwater practices and their associated regulations and design standards used in the coastal plain were borrowed from the Piedmont physiographic region and were seldom adapted for the coastal plain conditions," that is changing and there are considerations to coastal conditions in some more recent design criteria and guidance (GA EPD, 2009; Perrin et al., 2009; Ellis et al., 2014; NC DEQ, 2017). Design manuals can be a critical link to the public sector (Harrington and Hsu, 2018). Still, decisions related to choosing a stormwater pond as the preferred BMP are often made "upstream" at the permitting agency and developer/homebuilder levels, and maintenance restrictions or requirements are often written into local codes and covenants (such as for a Home Owner's Association), so the "downstream" parties often have limited decision-making power over BMP selection, function, and maintenance plans.

While planning for the future is objectively important, flexibility in top-down policy implementation, such as is the case for stormwater in the U.S., may be beneficial for adaptive management of stormwater practices at the local level. Importantly, government and non-government actors tend to take on different roles for green infrastructure adoption and management; as reviewed by Harrington and Hsu (2018), government acts as "driver, coordinator and capacity-builder," while non-governmental actors often lead in informationsharing. Ad-hoc collaborative networks can be key to adaptive capacity in such systems (Dow et al., 2013). Where consumers and other stakeholders are knowledgeable and empowered, there are cases of market forces driving innovation and implementation, such as due to cost savings or home-owner preference for low-impact development (e.g., US EPA, 2013). Further study is needed for how policy and organizational structures may be optimized to integrate water resource management science and practice involving communities.

\section{CRITICAL RESEARCH NEEDS}

\section{Increased Monitoring to Understand Pond Function}

Data availability is a major limitation on developing an improved understanding of stormwater pond function and their impact on human and ecological health. Persaud et al. (2016), in their study of stormwater non-point source pollutant management, indicate that routine water quality measurements are rarely performed in stormwater ponds, but that this data is desired by 
community members. Even fewer studies of stormwater ponds collect long-term (DeLorenzo et al., 2012) or high frequency water quality data (Harper and Baker, 2007; AMEC, 2012), and reviews of the existing literature indicate that controlling factors such as bathymetry and hydraulic retention time are not always reported (Harper and Baker, 2007), nor are other pertinent environmental variables (Koch et al., 2014). There is very little data available pertaining to the seasonality of wet detention pond performance, and to the role they may play in either capturing or transferring emerging contaminants of concern (e.g., pharmaceuticals, hormones, microplastics, or antibiotic resistant bacteria).

Community-based or citizen science programs may help increase data availability, but time and resources will need to be made available for these efforts and achieving positive outcomes is not straight-forward-either in the view of quality control and assurance or demonstrating that engagement leads to improved water quality (Betts and Alsharif, 2014; Scott and Frost, 2017). There are several examples of programs within the region that engage citizens in water quality monitoring through collaboration with non-profit or university groups that mostly monitor stream or river waters, but a few programs from Florida have a focus on lakes or ponds (Canfield et al., 2002; Betts and Alsharif, 2014; Hoyer et al., 2014). Establishing a broad, longer-term record of water quality provides citizens, managers and other stakeholders with data that is needed to improve the decision-making process, including changing management practices (Serrano and DeLorenzo, 2008) and formulating state and local codes or ordinances. Surveying the number, location and dimensions of stormwater ponds will also be necessary for understanding their overall impact on hydrology and pollutant fate and transport in the coastal region.

\section{Performance Evaluation and Criteria}

Since the implementation of stormwater control regulations and guidelines, careful calculations of stormwater pond design have been enacted in the field, yet audits of design details to measured performance are lacking. Uncertainties in performance and cost of BMPs for different settings is a critical factor that impedes sustainable watershed-scale stormwater management (Roy et al., 2008). One needed area of continued investigation in the southeastern U.S. coastal region is in the design and "lifetime" of ponds with respect to water quantity and quality performance. Many states recommend maintenance activities to restore function that are benchmarked according to maintaining a certain water volume (e.g., SC DHEC, 2005; FDOT, 2015). But, are these recommendations optimal, i.e., suited for the coastal plain physical geography? To achieve a desired pollution removal, changing wet detention pond design criteria to be based on residence time rather than volume, such as recommended for policy updates in the State of Florida (Harper and Baker, 2007), may be more in line with the growing body of research on wet detention pond performance and allow for performance to be maintained under potential changes in environmental conditions. North Carolina recently updated design standards for sizing wet detention ponds to allow the use of hydraulic retention time (NC DEQ, 2017). Keeping ponds in compliance with these criteria is the next step. Looking into the future, analyses are also warranted of how ponds affect coastal community vulnerability during major storm events and how changing climate with alterations in precipitation patterns and tides may impact function under existing design. It is also important to ascertain how stormwater management policy specifically in relation to wet ponds may need to be updated to address undesirable down-stream effects that may occur even during storms that are less intense than "design" conditions (e.g., channel geomorphic change; Roesner et al., 2001; Bledsoe et al., 2012).

Correct placement of wet detention ponds but also evaluation of how they may work in combination with other stormwater management practices (both structural and non-structural) within a site and on a watershed-basis is needed. This is based on some observations that wet detention ponds with close connections to estuarine systems may pose unacceptable health risks to human and ecological receptors as presently designed and operated, such as by transmitting toxic pollutants, algae, and bacteria (Lewitus et al., 2008; Baalousha et al., 2018). Rather than single ponds, ponds of differing designs in series or a "treatment train" of several different BMP types may be required in places in order to achieve the various performance metrics expected for stormwater management. For instance, there are trade-offs in pond design (e.g., depth) that influence phosphorus and nitrogen removal differently (Koch et al., 2014; Gold et al., 2019). Given the complexity of environmental systems and the number of variables involved, site-specific models may help elucidate wet detention pond function. Knowledge of fate and transport mechanisms has been translated into models that aim to predict pollutant concentrations and loads through stormwater systems to inform engineering and management (Elliot and Trowsdale, 2007; Vezzaro et al., 2011, 2012; Fletcher et al., 2013; Bell et al., 2019). However, it has been reviewed that improvement of biophysical models will require more monitoring data for calibration and field testing, and improved understanding of fate processes and management outcomes for a wider selection of environmental contaminants (BertrandKrajewski, 2007; Elliot and Trowsdale, 2007; Gold et al., 2019). Convenient modeling tools are also being developed to enhance the ability of planners and construction engineers to determine the best site location for wet detention ponds in coastal regions (Johnson and Sample, 2017).

Yet, the question still remains whether some coastal plain areas may be better served by other stormwater management approaches. The approach to install wet detention basins throughout the coastal plain is a narrow technological solution to stormwater control and may be built on history of use and confidence in the absence of information in tandem with certain motivations, such as the benefit of using excavated soil for fill material elsewhere (Law et al., 2008) and the basin for sediment trapping during construction activities, the potential for stormwater ponds to be perceived as amenities by homebuyers, and the convenience and potentially lower cost relative to other approaches. One manner by which wet detention ponds may be failing on the landscape-level is in the way routing of stormwater directly to ponds via street drains and pipes results in limited soil infiltration and processing potential 
of nutrients and organic matter. Infiltration may remove pollutants found in urban stormwater by various mechanisms, including filtration, sorption, and biochemical transformation (Grebel et al., 2013). Lack of soil infiltration additionally may starve coastal waters of the dissolved minerals and organic matter profile that characterizes the pre-development blackwater streams of much of the southeastern U.S. coastal plain watersheds (Gold et al., 2017b). Cycles of vegetation blooms and control via herbicides represent a manmade ecological system severely out of equilibrium and can have down-stream effects through connections with groundwater and/or surface waters. One study which evaluated implementation of wet ponds in coastal North Carolina on a watershed scale found a failure to mitigate many negative water quality impacts of development (Gold et al., 2017b)-more such studies are needed. Among a sample of stormwater pond professionals in coastal SC there was mixed response as to whether stormwater ponds were the best tool for management (Dickes et al., 2016). Need for more research into alternative management methods, incentives for low impact development and improved design criteria were commonly cited among survey respondents (Dickes et al., 2016).

Arguably the largest opportunities for redesigning stormwater management systems lie in currently developing areas (e.g., National Research Council (NRC), 2008). Although infrastructure "lock-in" (Markolf et al., 2018) presents barriers to change, retrofits are also possible, especially considering that many older stormwater detention ponds may be approaching major maintenance milestones. Stormwater ponds and other green infrastructure designs may be adapted for coastal plain hydrogeologic conditions (e.g., Gregory et al., 2011). Nonstructural controls, such as through upland management and community engagement around stormwater issues (e.g., pollution reduction, disconnecting downspouts, vegetative buffer management, etc.), are also important elements that could be advanced in many areas of the southeastern U.S. (DeLorenzo et al., 2012; Persaud et al., 2016). It is important for watershed management to be an inclusive process, and to not have "debates around [development] strategies... materially and discursively reinforce forms of inequality on the landscape" (Finewood, 2012). Evaluating practices and encouraging a multi-pathway approach to management is not a novel recommendation (e.g., Roy et al., 2008), but we emphasize that prioritization of resources and policy mechanisms are needed toward this goal.

\section{Science and Practice: Multidisciplinary Frameworks}

As researchers and stormwater professionals move from documenting water quality and quantity performance and engineering design and into the realm of scientific outreach, restoration, or advocating for structural and non-structural changes to urban development, success will depend on how well place-based social, political, and economic factors are interwoven (Thornton and Laurin, 2005; Barbosa et al., 2012; Betts and Alsharif, 2014; Young et al., 2014; Monaghan et al., 2016; Persaud et al., 2016; Dhakal and Chevalier, 2017;
Markolf et al., 2018). Thornton and Laurin (2005) aptly refer to the prerequisite for social sciences and marketing in environmental sustainability as "soft sciences and the hard reality of lake management." Improving stormwater management in general, and wet pond implementation in particular, will undoubtedly require collaboration between a variety of professional fields. Venn diagrams have been used by other researchers to conceptualize the interdisciplinary nature of integrated stormwater management, for instance by illustrating overlapping economy/regulatory, ecology, and society/institutions (Thornton and Laurin, 2005), or with engineering/technological, environmental, and social components (Markolf et al., 2018; Prudencio and Null, 2018). Markolf et al. (2018) describe bidirectional interactions between these infrastructure system components. Going further, Flynn and Davidson (2016) describe urban stormwater socialecological systems by defining key attributes in 9 tiered categories relating to: social, economic, and political settings, ecosystems, resources, governance systems, actors, interactions between components and outcomes. Examples of attributes modified specifically for green infrastructure in this framework (and category) include: stormwater ordinances, funding scheme and management plans (governance systems); local ecological knowledge, technical expertise, operation and maintenance, and perceptions/attitudes (actors); and soil characteristics, imperviousness and functionality (resource systems) (for expanded list and definitions, see Flynn and Davidson, 2016).

Given the multiple dimensions involved, social-ecological (e.g., Flynn and Davidson, 2016) or social-ecologicaltechnological systems (e.g., Markolf et al., 2018) frameworks are the next step toward recognizing interactions between system components in order to realize pathways for communicating and attaining shared development goals in concert with environmental protection. These system frameworks may help identify system vulnerabilities and advance sound management by elucidating interconnections among stakeholders and influential factors in the decision-making process, since feedback mechanisms operate between technological, social, and ecological domains. Coupled socio-biophysical models are computationally and methodologically challenging but represent a critical opportunity for understanding vulnerability in stormwater management systems (Eakin et al., 2017). As a precautionary example, within current practices, stormwater ponds morphed in design to accommodate mostly economic goals of increasing lake-front property, in Florida for instance, have been termed "ticking time bombs" for coastal water quality (Thomas, 2014). Failure to thoroughly evaluate stormwater pond performance (technological and social) reflects the barriers to full green infrastructure implementation that have been outlined by others, including social acceptance, availability of expertise, and leadership (e.g., Dhakal and Chevalier, 2017), the inherent complexity of environmental systems (Drescher et al., 2011) and the growing complexity of infrastructure systems (Markolf et al., 2018), and the methodological challenges in interdisciplinary systems research (Eakin et al., 2017; Partelow, 2018). Avenues are needed for supporting this type of collaborative work around stormwater management, such as in the southeastern U.S. 


\section{CONCLUSIONS}

In summary, the ability of wet detention ponds to attenuate peak flows and remove pollutants to protect downstream water bodies are affected by stormwater pond position in the landscape, how this impacts hydrological and biogeochemical processes, policies on design, and management practices. Where the existing knowledge base needs to be expanded to suit the needs in the southeastern U.S. coastal plain is to recognize how the unique hydrogeologic and climatic setting, in addition to socio-political factors, may differ regionally, and perhaps in contrast to other climatic and topographic zones where stormwater pond research and management case studies have been conducted.

A large number of ponds, and various engineered designs, uses, and management approaches, together make the overall impact of stormwater ponds on water flow and quality in the southeastern coastal plain difficult to ascertain. Due to practicality and scaling issues, and the need for even the most fundamental of performance data, studies have typically focused on individual or parcel-level pond observations. There is a need to integrate engineering, chemical and biological sciences with hydrology to better understand pollution removal capability and to forecast functionality, from the unit-scale to the watershedscale, under changing hydrologic conditions. However, the sociopolitical aspects of stormwater pond design preference, use, maintenance and stewardship cannot be overlooked. In the dynamic and rapidly-developing coastal zone of the southeastern

\section{REFERENCES}

Amatya, D. M., Muwamba, A., Panda, S., Callahan, T., Harder, S., and Pellett, C. A. (2018). Assessment of spatial and temporal variation of potential evapotranspiration estimated by four methods for South Carolina. J. South Carolina Water Res. 5, 3-24. Available online at: https://tigerprints.clemson. $\mathrm{edu} / \mathrm{jscwr} / \mathrm{vol} 5 / \mathrm{iss} 1 / 5$

AMEC (2012). City of Naples Stormwater Quality Analysis, Pollutant Loading and Removal Efficiencies. Final Report, Project Number 6063-10-0182. Newberry, FL: AMEC Environment Infrastructure, Incorporated.

Anderson, B. C., Watt, W., E., and Marsalek, J. (2002). Critical issues for stormwater ponds: learning from a decade of research. Water Sci. Technol. 45:277-283. doi: 10.2166/wst.2002.0258

Baalousha, M., McNeal, S., and Scott, G. I. (2018). "Chapter 3: Non-point source (NPS) pollutants," in Stormwater Ponds in Coastal South Carolina: Inventory and State of the Knowledge Report, eds B. E. Cotti-Rausch and M. R. DeVoe (Charleston, SC: SC Sea Grant Consortium), 39.

Barbosa, A. E., Fernandes, J. N., and David, L. M. (2012). Key issues for sustainable urban stormwater management. Water Res. 46, 6787-6798. doi: 10.1016/j.watres.2012.05.029

Barile, P. (2018). Widespread sewage pollution of the Indian River Lagoon system, Florida (USA) resolved by spatial analyses of macroalgal biogeochemistry. Mar. Pollut. Bull. 128, 557-574. doi: 10.1016/j.marpolbul.2018. 01.046

Bell, C. D., Tague, C. L., and McMillan, S. K. (2019). Modeling runoff and nitrogen loads from a watershed at different levels of impervious surface coverage and connectivity to storm water control measures. Water Resour. Res. 55, 2690-2707. doi: 10.1029/2018WR023006

Bertrand-Krajewski, J.-L. (2007). Storwmater pollutant loads modelling: epistemological aspects and case studies on the influence of field data sets on calibration and verification. Water Sci. Technol. 55, 1-17. doi: $10.2166 /$ wst. 2007.090
U.S., combining knowledge areas with a systems perspective is needed.

\section{AUTHOR CONTRIBUTIONS}

$\mathrm{BB}, \mathrm{TC}$, and VV contributed to the conception, drafting, and revision of this manuscript.

\section{FUNDING}

Funding to support this work, including literature review and workshops, was received from the South Carolina Sea Grant Consortium. The Department of Geology and Environmental Geosciences supported open access publication fees.

\section{ACKNOWLEDGMENTS}

This extended review article was inspired by our chapter (Vulava et al., 2018) contribution to a State of the Knowledge Report published by the South Carolina Sea Grant Consortium (www.scseagrant.org/pdf_files/Stormwater-Ponds-ExecutiveSummary.pdf). The authors would like to acknowledge the helpful discussions within the South Carolina Stormwater Ponds Research and Management Collaborative and to specifically thank Kathryn Ellis for help with literature review, Landon Knapp for producing maps and census statistics, and Bridget Cotti-Rausch and Amy Scaroni for comments on drafts.

Betts, A. T., and Alsharif, K. A. (2014). Assessment of a countywide stormwater pond improvement program. Urban Water J. 11, 11-19. doi: 10.1080/1573062X.2012.750370

Blair, A., Lovelace, S., Sanger, D., Holland, A. F., Vandiver, L., and White, S. (2014a). Exploring impacts of development and climate change on stormwater runoff. Hydrol. Process. 28, 2844-2854. doi: 10.1002/hyp.9840

Blair, A., and Sanger, D. (2016). Climate change and watershed hydrologyheavier precipitation influence on stormwater runoff. Geosciences 6:34. doi: 10.3390/geosciences6030034

Blair, A., Sanger, D., White, D., Holland, A. F., Vandiver, L., Bowker, C., et al. (2014b). Quantifying and simulating stormwater runoff in watersheds. Hydrol. Process. 28, 559-569. doi: 10.1002/hyp.9616

Blecken, G.-T., Hunt, W. F. I. I. I., Al-Rubaei, A. M., Viklander, M., and Lord, W. G. (2017). Stormwater control measure (SCM) maintenance considerations to ensure designed functionality. Urban Water J. 14, 278-290. doi: 10.1080/1573062X.2015.1111913

Bunker, K. (2004). A hydrological assessment of two detection ponds watersheds in an urban coastal landscape (M. S. Thesis). College of Charleston, Charleston, SC, United States.

Burnett, J. W., and Mothorpe, C. (2018). "Chapter 6: An economic assessment of coastal stormwater management," in Stormwater Ponds in Coastal South Carolina: Inventory and State of the Knowledge Report, eds B. E. Cotti-Rausch and M. R. DeVoe (Charleston, SC: SC Sea Grant Consortium), 21.

Callahan, K. A., Scaroni, A. E., Wallover, G. C., Weathers, M., and Neal, A. (2018). "Chapter 7: Communication strategy for improved pond awareness," in Stormwater Ponds in Coastal South Carolina: Inventory and State of the Knowledge Report, eds B. E. Cotti-Rausch and M. R. DeVoe (Charleston, SC: SC Sea Grant Consortium), 15.

Callahan, T. J., Amatya, D. M., and Stone, P. A. (2017). Coastal forests and groundwater: using case studies to understand the effects of drivers and stressors for resource management. Sustainability 9:447. doi: $10.3390 /$ su9030447 
Canfield, D. E., Brown, C. D., Bachmann, R. W., and Hoyer, M. V. (2002). Volunteer lake monitoring: testing the reliability of data collected by the Florida LAKEWATCH program. Lake Reser. Manag. 18, 1-9. doi: $10.1080 / 07438140209353924$

Carter, L., Terando, A., Dow, K., Hiers, K., Kunkel, K. E., Lascurain, A., et al. (2018). "Southeast," in Impacts, Risks, and Adaptation in the United States: Fourth National Climate Assessment, Vol. II, eds D. R. Reidmiller, C. W. Avery, D. R. Easterling, K. E. Kunkel, K. L. M. Lewis, T. K. Maycock, et al. (Washington, DC: U.S. Global Change Research Program), 743-808.

Chang, N.-B., Lu, J.-W., Chui, T. F. M., and Hartshorn, N. (2018). Global policy analysis of low impact development for stormwater management in urban regions. Land Use Policy 70, 368-383. doi: 10.1016/j.landusepol.2017. 11.024

Chiandet, A. S., and Xenopoulos, M. A. (2016). Landscape and morphometric controls on water quality in stormwater management ponds. Urban Ecosyst. 19, 1645-1663. doi: 10.1007/s11252-016-0559-8

DeLorenzo, M. E., and Fulton, M. H. (2009). Water Quality and Harmful Algae in Southeastern Coastal Stormwater Ponds. NOAA Technical Memorandum NOS NCCOS. Charleston, SC: NOAA/National Ocean Service/National Centers for Coastal Ocean Science.

DeLorenzo, M. E., Thompson, B., Cooper, E., Moore, J., and Fulton, M. H. (2012). A long-term monitoring study of chlorophyll, microbial contaminants, and pesticides in a coastal residential stormwater pond and its adjacent tidal creek. Environ. Monit. Assess. 184, 343-359. doi: 10.1007/s10661-011-1972-3

Dhakal, K. P., and Chevalier, L. R. (2017). Managing urban stormwater for urban sustainability: barriers and policy solutions for green infrastructure application. J. Environ. Manag. 203, 171-181. doi: 10.1016/j.jenvman.2017.07.065

Dickes, L. A., Allen, J., Jalowiecka, M., and Buckely, K. (2016). A policy lens of South Carolina coastal stormwater management. J. South Carolina Water Res. 3, 31-41. Available online at: https://tigerprints.clemson.edu/jscwr/vol3/iss1/5

Dolowitz, D. P. (2015). Stormwater management the American way: why not policy transfer? Environ. Sci. 2, 868-883. doi: 10.3934/environsci.2015. 3.868

Dow, K., Haywood, B. K., Kettle, N. P., and Lackstrom, K. (2013). The role of ad hoc networks in supporting climate change adaptataion: a case study from the Southeastern United States. Reg. Environ. Change 13, 1235-1244. doi: 10.1007/s10113-013-0440-8

Drescher, S. R., Law, N. L., Caraco, D. S., Cappiella, K. M., Schneider, J. A., and Hirschman, D. J. (2011). Research and policy implications for watershed management in the Atlantic Coastal Plain. Coast. Manag. 39, 242-258. doi: $10.1080 / 08920753.2011 .566123$

Drescher, S. R., Messersmith, M. J., Sanger, D. M., and Davis, B. C. (2007). State of Knowledge Report: Stormwater Ponds in the Coastal Zone. South Carolina Department of Health and Environmental Control, Office of Ocean and Coastal Resource Management.

Eakin, H., Bojorquez-Tapia, L. A., Janssen, M. A., Georgescu, M., ManuelNavarrete, D., Vivoni, E. R., et al. (2017). Opinion: urban resilience efforts must consider social and political forces. Proc. Natl. Acad. Sci. U.S.A. 114, 186-189. doi: $10.1073 /$ pnas. 1620081114

Elliot, A. H., and Trowsdale, S. A. (2007). A review of models for low impact urban stormwater drainage. Environ. Model. Softw. 22, 394-405. doi: 10.1016/j.envsoft.2005.12.005

Ellis, K., Berg, C., Caraco, D., Drescher, S., Hoffmann, G., Keppler, B., et al. (2014). Low Impact Development in Coastal South Carolina: A Planning and Design Guide. ACE Basin and North Inlet-Winyah Bay National Estuarine Research Reserves, 462. Available online at: http://www.scseagrant.org/pdf_files/LID-inCoastal-SC-low-res.pdf

Epps, T. H., Hitchcock, D. R., Jayakaran, A. D., Loflin, D. R., Williams, T. M., and Amatya, D. M. (2012). Characterization of storm flow dynamics of headwater streams in the South Carolina lower coastal plain. J. Am. Water Res. Assoc. 49, 76-89. doi: 10.1111/jawr.12000

FDOT (2015). Best Maintenance Practices for Stormwater Runoff, Designer and Review Manual. Prepared by Stormwater Management Academy, University of Central Florida, Orlando, FL. Accessed online at: http://www.fdot.gov/ maintenance/RDW/BestMaintPracticesSWRunoff.pdf (accessed July 18, 2017).

Fennessey, L. A., Hamlett, J. M., Aron, G., and LaSota, D. (2001). Changes in runoff due to stormwater management pond regulations. J. Hydrol. Eng. 6, 317-327. doi: 10.1061/(ASCE)1084-0699(2001)6:4(317)
Finewood, M. H. (2012). Feeling the squeeze: a political ecology of race and amenity-based development in coastal Bluffton, South Carolina. Local Environ. 17, 991-1011. doi: 10.1080/13549839.2012.688733

Fletcher, T. D., Andrieu, H., and Hamel, P. (2013). Understanding, management and modelling of urban hydrology and its consequences for receiving waters: a state of the art. Adv. Water Res. 51, 261-279. doi: 10.1016/j.advwatres.2012.09.001

Flynn, C. D., and Davidson, C. I. (2016). Adapting the social-ecological system framework for urban stormwater management: the case of green infrastructure adoption. Ecol. Soc. 21:19. doi: 10.5751/ES-08756-210419

GA EPD (2009). Coastal Stormwater Supplement to the Stormwater Management Manual, 1st Edn. Georgia Environmental Protection Division of the Department of Natural Resources, 542. Available online at: https://epd.georgia. gov/georgia-epd-coastal-stormwater-supplement-stormwater-managementmanual

Galloway, D., Jones, D.R., and Ingebritsen, S.E. (Eds). (1999). Land Subsidence in the United States. Circular 1182, U. S. Geological Survey, Washington, D.C. Available online at: https://pubs.usgs.gov/circ/circ1182/

Ghermandi, A., and Fichtman, E. (2015). Cultural ecosystem services of multifunctional constructed treatment wetlands and waste stabilization ponds: time to enter the mainstream? Ecol. Eng. 84, 615-623. doi: 10.1016/j.ecoleng.2015.09.067

Gold, A. C., Thompons, S. P., and Piehler, M. F. (2017a). Coastal stormwater wet pond sediment nitrogen dynamics. Sci. Total Environ. 609, 672-681. doi: 10.1016/j.scitotenv.2017.07.213

Gold, A. C., Thompons, S. P., and Piehler, M. F. (2019). Nitrogen cycling processes within stormwater control measures: a review and call for research. Water Res. 149, 578-587. doi: 10.1016/j.watres.2018.10.036

Gold, A. C., Thompson, S. P., and Piehler, M. F. (2017b). Water quality before and after watershed-scale implementation of storwmater wet ponds in the coastal plain. Ecol. Eng. 105, 240-251. doi: 10.1016/j.ecoleng.2017.05.003

Gona, A. (2016, 22 December). New stormwater rules set to take effect. Coastal Review Online. Available online at: https://www.coastalreview.org/2016/12/ new-stormwater-rules-set-take-effect/

Greb, S. R., and Bannerman, R. T. (1997). Influence of particle size on wet pond effectiveness. Water Environ. Res. 69, 1134-1138. doi: 10.2175/106143097X125876

Grebel, J. E., Mohanty, S. J., Torkelson, A. A., Boehm, A. B., Higgins, C. P., Maxwell, R. M., et al. (2013). Engineered infiltration systems for urban stormwater reclamation. Environ. Eng. Sci. 30, 437-454. doi: $10.1089 /$ ees.2012.0312

Greenfield, D. I., Gooch Moore, J., Stewart, J. R., Hilborn, E. D., George, B. J., Li, Q., et al. (2017). Temporal and environmental factors driving Vibria vulnificus and V. Parahaemolyticus populations and their associations with harmful algal blooms in South Carolina detention ponds and receiving tidal creeks. GeoHealth 1, 306-317. doi: 10.1002/2017GH000094

Greenfield, D. I., Smith, E. M., Tweel, A. W., Sanger, D. A., and Sitta, K. (2018). "Chapter 4: Stormwater pond ecology," in Stormwater Ponds in Coastal South Carolina: Inventory and State of the Knowledge Report, eds B. E. Cotti-Rausch and M. R. DeVoe (Charleston, SC: SC Sea Grant Consortium), 22.

Gregory, J., Cunningham, B., Ammeson, L., Clark, M., and Hull, H. C. (2011). Modifying low-impact development practices for Florida watersheds. Florida Watersh. J. 4, 7-11.

Harder, S. V., Amatya, D. M., Callahan, T. J., Trettin, C. C., and Hakkila, J. (2007). Hydrology and water budget for a forested Atlantic coastal plain watershed, South Carolina. J. Am. Water Res. Assoc. 43, 563-575. doi: $10.1111 / j .1752-1688.2007 .00035 . x$

Harper, H. H., and Baker, D. M. (2007). Evaluation of Current Stormwater Design Criteria Within the State of Florida. Final Report June 2007. Prepared for Florida Department of Environmental Protection. Available online at: http://www. devoeng.com/memos/SW_TreatmentReportFinal_71907.pdf (accessed July 18, 2018).

Harrington, E., and Hsu, D. (2018). Roles for government and other sectors in the governance of green infrastructure in the U. S. Environ. Sci. Policy 88, 104-115. doi: 10.1016/j.envsci.2018.06.003

Hassall, C., and Anderson, S. (2015). Stormwater ponds can contain comparable biodiversity to unmanaged wetlands in urban areas. Hydrobiologia 745 , 137-149. doi: 10.1007/s10750-014-2100-5 
Hathaway, J. M., Hunt, W. F., and Jadlocki, S. (2009). Indicator bacteria removal in storm-water best management practices in Charlotte, North Carolina. J. Environ. Eng. 135, 1275-1285. doi: 10.1061/(ASCE)EE.1943-7870.0000107

Hoyer, M. V., Bigham, D. L., Bachman, R. W., and Canfield, D. E. (2014). Florida LAKEWATCH: citizen scientists protecting Florida's aquatic systems. Florida Sci. 77, 184-197.

Johnson, R. D., and Sample, D. J. (2017). A semi-distributed model for locating stormwater best management practices in coastal environments. Environ. Model. Softw. 91, 70-86. doi: 10.1016/j.envsoft.2017.01.015

Kirkwood, K. (2009). Analysis of Fishkills in SC, 1990-2005 (Master Practicum). Department of Environmental health Sciences, Arnold School of Public Health, University of South Carolina, Columbia, SC

Koch, B. J., Febria, C. M., Gevrey, M., Wainger, L. A., and Palmer, M. A. (2014). Nitrogen removal by stormwater management structures: a data synthesis. $J$. Am. Water Res. Assoc. 50, 1594-1607. doi: 10.1111/jawr.12223

Lapointe, B. E., Herren, L. W., Debortoli, D. D., and Vogel, M. A. (2015). Evidence of sewage-driven eutrophication and harmful algal blooms in Florida's Indian River Lagoon. Harmful Algae 43, 83-102. doi: 10.1016/j.hal.2015.01.004

Law, N. L., Cappiella, K., Lasher, L., and Swann, C. (2008). Technical Memorandum: Watershed Planning Needs Survey of Coastal Plain Communities. Prepared for Cooperative Institute for Coastal and Estuarine Environmental Technology, Center for Watershed Protection, Ellicot City, MD.

Lewitus, A. J., Brock, L. M., Burke, M. K., DeMattio, K. A., and Wilde, S. B. (2008). Lagoonal stormwater detention ponds as promoters of harmful algal blooms and eutrophication along the South Carolina coast. Harmful Algae 8, 60-65. doi: 10.1016/j.hal.2008.08.012

Lewitus, A. J., Schmidt, L. B., Mason, L. J., Kempton, J. W., Wilde, S. B., Wolny, J. L., et al. (2003). Harmful algal blooms in South Carolina residential and golf course ponds. Popul. Environ. 24, 387-413. doi: 10.1023/A:1023642908116

Mallin, M. A., Ensign, S. H., Wheeler, T. L., and Mayes, D. B. (2002). Pollutant removal efficacy of three wet detention ponds. J. Environ. Q. 31, 654-660. doi: $10.2134 /$ jeq2002.6540

Manson, S., Schoreder, J., Van Riper, D., and Ruggles, S. (2018). IPUMS National Historical Geographic Information System: Version 13.0 [Database]. Minneapolis, MN: University of Minnesota.

Markolf, S. A., Chester, M. V., Eisenberg, D. A., Iwaniec, D. M., Davison, D. I., Zimmerman, R., et al. (2018). Interdependent infrastructure as linked social, ecological, and technical systems (SETSs) to address lock-in and enhance resilence. Earth Future 6, 1638-1659. doi: 10.1029/2018EF0 00926

McCabe, K. M., Smith, E.M., Lang, S.Q., Osburn, C. L., and Benitez-Nelson, C. R. (2021). Particulate and Dissolved Organic Matter in Stormwater Runoff Influences Oxygen Demand in Urbanized Headwater Catchments. Environ. Sci. Technol. 55, 952-961. doi: 10.1021/acs.est.0c04502

McPhillips, L. E., and Matsler, A. M. (2018). Temporal evolution of green stormwater infrastructure strategies in three US cities. Front. Built Environ. 4:26. doi: 10.3389/fbuil.2018.00026

Messersmith, M. J. (2007). Assessing the hydrology and pollutant removal efficiencies of wet detention ponds in South Carolina. (M. S. Thesis), College of Charleston, Charleston, SC, United States.

Monaghan, P., Hu, S., Hansen, G., Ott, E., Nealis, C., and Morera, M. (2016). Balancing the ecological function of residential stormwater ponds with homeowner landscaping practices. Environ. Manag. 58, 843-856. doi: 10.1007/s00267-016-0752-9

Moore, T. L., Rodak, C. M., and Vogel, J. R. (2017). Urban stormwater characterization, control, and treatment. Water Environ. Res. 89, 1876-1927. doi: 10.2175/106143017X15023776270692

Moore, T. L. C., and Hunt, W. F. (2012). Ecosystem service provision by stormwater wetlands and ponds - A means for evaluation? Water Res. 46, 6811-6823. doi: 10.1016/j.watres.2011.11.026

National Research Council (NRC) (2008). Urban Stormwater Management in the United States. Water Science and Technology Board, Committee on Reducing Stormwater Discharge Contributions to Water Pollution. National Academies Press, Washington, DC.

NC DEQ (2017). Stormwater Design Manual, Part C-3. Wet Pond. Available online at: https://deq.nc.gov/about/divisions/energy-mineral-land-resources/energy- mineral-land-permit-guidance/stormwater-bmp-manual (accessed April 18, 2018).

NOAA (2013). National Coastal Population Report. March 2013. Avaialble online at: https://aamboceanservice.blob.core.windows.net/oceanservice-prod/facts/ coastal-population-report.pdf

NOAA (2018). Patterns and Projections of High Tide Flooding Along the U.S. Coastline Using a Common Impact Threshold. NOAA Technical Report NOS CO-OPS 086. Silver Spring, MD: National Ocean Service.

NOAA (2019). Supplemental East Central Florida Climate Data. National Weather Service, Melbourne, FL. Available online at: https://www.weather.gov/mlb/ climate (accessed March 18, 2019).

NOEP (2016). State of the U. S. Ocean and Coastal Economies: 2016 Update. National Ocean Economics Program, 35.

Partelow, S. (2018). A review of the social-ecological systems framework: applications, methods, modifications, and challenges. Ecol. Soc. 23:36. doi: 10.5751/ES-10594-230436

Perrin, C., Milburn, L., Szpir, L., Hunt, W., Bruce, S., McLendon, R., et al. (2009). Low Impact Developemnt: A Guidebook for North Carolina (AG-716). NC Cooperative Extension Service, NC State Unviersity. Available online at: http:// www.ncsu.edu/WECO/LID

Persaud, A., Alsharif, K., Monaghan, P., Akiwumi, F., Morera, M. C., and Ott, E. (2016). Landscaping practices, community perceptions, and social indicators for stormwater nonpoint source pollution management. Sust. Cities Soc. 27, 377-385. doi: 10.1016/j.scs.2016.08.017

Persson, J., and Wittgren, H. B. (2003). How hydrological and hydraulic conditions affect performance of ponds. Ecol. Eng. 21, 259-269. doi: 10.1016/j.ecoleng.2003.12.004

Prudencio, L., and Null, S. E. (2018). Stormwater management and ecosystem services: a review. Environ. Res. Lett. 13, 1-13. doi: 10.1088/1748-9326/aaa81a

Pyzoha, J. E., Callahan, T. J., Sun, G., Trettin, C. C., and Miwa, M. (2008). A conceptual hydrologic model for a forested Carolina bay depressional wetland on the Coastal Plain of South Carolina, USA. Hydrol. Process. 22, 2689-2698. doi: 10.1002/hyp.6866

Roesner, L. A., Bledsoe, B. P., and Brashear, R. W. (2001). Are best-managementpractice criteria really environmentally friendly? J. Water Res. Plan. Manag. 178, 150-154. doi: 10.1061/(ASCE)0733-9496(2001)127:3(150)

Roy, A. H., Wenger, S. J., Fletcher, T. D., Walsh, C. J., Ladson, A. R., Shuster, W. D., et al. (2008). Impediments and solutions to sustainable, watershed-scale urban stormwater management: lessons from Australia and the United States. Environ. Manag. 42, 344-359. doi: 10.1007/s00267-008-9119-1

Sanger, D., Blair, A., DiDonato, G., Washburn, T., Jones, S., Riekerk, G., et al. (2015). Impacts of coastal development on the ecology of tidal creek ecosystems of the US Southeast including consequences to humans. Estuar. Coasts 38, S49-S66. doi: 10.1007/s12237-013-9635-y

SC DHEC (2005). South Carolina Storm Water Management BMP Handbook. South Carolina Department of Health and Environmental Control, Columbia, SC. Available online at: http://www.scdhec.gov/Environment/WaterQuality/ Stormwater/BMPHandbook/

Scholes, L., Revitt, D. M., and Ellis, J. B. (2008). A systematic approach for the comparative assessment of stormwater pollutant removal potentials. J. Environ. Manag. 88, 467-478. doi: 10.1016/j.jenvman.2007.03.003

Schroer, W. F., Benitez-Nelson, C. R., Smith, E. M., and Ziolkowski, L. A (2018). Drivers of sediment accumulation and nutrient burial in coastal stormwater detention ponds, South Carolina, USA. Ecosystems 21, 1118-1138. doi: 10.1007/s10021-017-0207-z

Serrano, L., and DeLorenzo, M. E. (2008). Water quality and restoration in a coastal subdivision stormwater pond. J. Environ. Manag. 88, 43-52. doi: 10.1016/j.jenvman.2007.01.025

Smith, E., Sanger, D., Tweel, A., and Koch, E. (2018). “Chapter 1: Pond landscape," in Stormwater Ponds in Coastal South Carolina: Inventory and State of the Knowledge Report, eds B. E. Cotti-Rausch and M. R. DeVoe (Charleston, SC: SC Sea Grant Consortium), 14.

Strecker, E. W., Quigley, M. M., Urbonas, B. R., Jones, J. E., and Clary, J. K. (2001). Determining urban storm water BMP effectiveness. J. Water Res. Plan. Manag. 127, 144-149. doi: 10.1061/(ASCE)0733-9496(2001)127:3(144)

Terando, A. J., Costanza, J., Belyea, C., Dunn, R. R., McKerrow, A., and Collazo, J. A. (2014). The southern megalopolis: Using the past to predict 
the future of urban sprawl in the southeast U. S. PLoS ONE 9:e102261. doi: 10.1371/journal.pone.0102261

Thapalia, A., Borrok, D. M., Van Metre, P. C., Musgrove, M., and Landa, E. R. (2010). $\mathrm{Zn}$ and $\mathrm{Cu}$ isotopes as tracers of anthropogenic contamination in a sediment core from an urban lake. Environ. Sci. Technol. 44, 1544-1550. doi: 10.1021/es902933y

Thomas, S. (2014). "Wet detention stormwater treatment ponds: thousands of ticking time bombs for water quality in southwest Florida," in 23rd Annual Southwest Florida Water Resources Conference. 31 January 2013. Available online at: https://awraflorida.org/resources/Documents/Newsletters/ 2014/2014_February_Watershed.pdf (accessed July 18, 2018)

Thomas, S., and Lucius, M. (2016). Groundwater seepage nutrient loading in a recently dug wet detention stormwater pond. Florida Sci. 79, 132-146.

Thornton, K., and Laurin, C. (2005). Soft sciences and the hard reality of lake management. Lake Reser. Manag. 21, 203-208. doi: 10.1080/07438140509354429

Tixier, G., Lafont, M., Grapentine, L., Rochfort, Q., and Marsalek, J. (2011). Ecological risk assessment of urban stormwater ponds: literature review and proposal of a new conceptual approach providing ecological quality goals and the associated bioassessment tools. Ecol. Indicat. 11, 1497-1506. doi: $10.1016 /$ j.ecolind.2011.03.027

U.S. Census Bureau (2011). Census Summary File 1 - United States [machinereadable data files]. Accessed at online http://www.census.gov

U.S. EPA (2009). Stormwater Wet Pond and Wetland Management Guidebook. Report No. EPA 833-B-09-001. Available onlinbe at: https://www3.epa.gov/ npdes/pubs/pondmgmtguide.pdf

Underwood, E. (2018). What is a nuisance flood, exactly?, Eos, 99, doi: 10.1029/2018EO103653

US EPA (2013). Case Studies Analyzing the Economic Benefits of Low Impact Development and Green Infrastructure Programs. EPA 841-R-13-004. U.S. Environmental Protection Agency Office of Wetlands, Oceans and Watersheds, Washington, DC. Available online at: http://water.epa.gov/polwaste/green/ upload/lid-gi-programs_report_8-6-13_com-bined.pdf

Van Metre, P. C., Mahler, B. J., and Furlong, E. T. (2000). Urban sprawl leaves its PAH signature. Environ. Sci. Technol. 34, 4064-4070. doi: 10.1021/es99 $1007 \mathrm{n}$

Vezzaro, L., Eriksson, E., Ledin, A., and Mikkelsen, P. S. (2011). Modelling the fate of organic micropollutants in stormwater ponds. Sci. Total Environ. 409, 2597-2606. doi: 10.1016/j.scitotenv.2011.02.046

Vezzaro, L., Eriksson, E., Ledin, A., and Mikkelsen, P. S. (2012). Quantification of uncertainty in modelled partitioning and removal of heavy metals $(\mathrm{Cu}, \mathrm{Zn})$ in a stormwater retention pond and a biofilter. Water Res. 46, 6891-6903. doi: 10.1016/j.watres.2011.08.047

Vulava, V., Beckingham, B., and Callahan, T. (2018). "Chapter 2: Transport and fate of contaminants in stormwater," in Stormwater Ponds in Coastal South
Carolina: Inventory and State of the Knowledge Report, eds B. E. Cotti-Rausch and M. R. DeVoe (Charleston, SC: SC Sea Grant Consortium), 25.

Walsh, C. J., Roy, A. H., Feminella, J. W., Cottingham, P. D., Groffman, P. M., and Morgan, R. P. (2005). The urban stream syndrome: current knowledge and search for the cure. J. North Am. Benthol. Soc. 24, 706-723. doi: 10.1899/04-028.1

Weinstein, J., Crawford, K. D., Garner, T. R., and Flemming, A. J. (2010). Screening-level ecological and human health risk assessment of polycyclic aromatic hydrocarbons in stormwater detention pond sediments of Coastal South Carolina, USA. J. Haz. Mat. 178, 906-916. doi: 10.1016/j.jhazmat.2010.02.024

Weiss, P. T., Gulliver, J. S., and Erickson, A. J. (2007). Cost and pollutant removal of storm-water treatment practices. J. Water Res. Plan. Manag. 133, 218-229. doi: 10.1061/(ASCE)0733-9496(2007)133:3(218)

Weiss, P. T., LeFevre, G., and Gulliver, J. S. (2008). Contamination of Soil and Groundwater Due to Stormwater Infiltration Practices, A Literature Review. St. Anthony Falls Laboratory, University of Minnesota, Minneapolis, MN.

Wilson, S. G., and Fischetti, T. R. (2010). Coastline Population Trends in the United States: 1960 to 2008. US Census Bureau Doc. No. P25-1139. Available online at: https://www.census.gov/prod/2010pubs/p25-1139.pdf

Wisniewski, N. L. (2014). The influence of nitrogen forms on the growth and toxin levels of microcystin-producing cyanobacteria in coastal stormwater detention ponds. (M. S. Thesis). College of Charleston, Charleston, SC, United States.

Young, R., Zanders, J., Lieberknecht, K., and Fassman-Beck, E. (2014). A comprehensive typology for mainstreaming urban green infrastructure. $J$. Hydrol. 519, 2571-2583. doi: 10.1016/j.jhydrol.2014.05.048

Bledsoe, B. P., Stein, E. D., Hawley, R. J., and Booth, D. (2012). Framework and tool for rapid assessment of stream susceptibility to hydromodication. J. Am. Water Resour. Assoc. 48, 788-808. doi: 10.1111/j.1752-1688.2012.00653.x

Scott, A. B., and Frost, P. C. (2017). Monitoring water quality in Toronto's urban stormwater ponds: assessing participation rates and data quality of water sampling by citizen scientists in FreshWater Watch. Sci. Tot. Environ. 592, 738-744. doi: 10.1016/j.scitotenv.2017.01.201

Conflict of Interest Statement: The authors declare that the research was conducted in the absence of any commercial or financial relationships that could be construed as a potential conflict of interest.

Copyright (C) 2019 Beckingham, Callahan and Vulava. This is an open-access article distributed under the terms of the Creative Commons Attribution License (CC BY). The use, distribution or reproduction in other forums is permitted, provided the original author(s) and the copyright owner(s) are credited and that the original publication in this journal is cited, in accordance with accepted academic practice. No use, distribution or reproduction is permitted which does not comply with these terms. 